\title{
Dealing with the Bad Loans of the Chinese Banks
}

\author{
By: John P. Bonin and Yiping Huang
}

Working Paper Number 357

January 2001 


\title{
Dealing with the Bad Loans of the Chinese Banks
}

\author{
John P. Bonin \\ Department of Economics \\ Wesleyan University \\ and \\ William Davidson Institute \\ University of Michigan School of Business
}

Yiping Huang

Salomon Smith Barney and Citibank

and

Australian National University 


\begin{abstract}
Chinese banks suffer from serious financial fragility manifested by high proportions of non-performing loans and low capital-adequacy ratios. A key policy introduced recently by the Chinese government to reduce financial risks is the establishment of four asset management companies (AMCs) for dealing with bad loans. Drawing on the experiences of the Resolution Trust Corporation in the United States and bank restructuring in the Central European transition economies, we argue that the original AMC design will not be successful in resolving the existing non-performing loans (NPLs) nor will it prevent the creation of new bad loans. We recommend a modification of the current proposal that redefines the relationships between the parent banks and the AMCs by transferring the deposits of problem enterprises along with their NPLs from parent banks to AMCs.
\end{abstract}

\title{
JEL Classification Numbers: G21, P34
}

Key words: Bad loans, State-owned banks, Asset Management Companies, China 


\section{Non-Technical Summary}

China's banking sector is dominated by four large multi-purpose, extensively branched, state-owned banks (SOBs) that account for more than $70 \%$ of both credits to enterprises and household deposits. From the late 1970s to the late 1990s, the financing responsibility for large state-owned enterprises (SOEs) shifted from the fiscal budget to these SOBs. During this period, fiscal revenues to GDP fell from $30 \%$ to $12 \%$ while bank loans to GDP increased from $50 \%$ to $120 \%$. By the mid-1990s, over one-half of SOEs were making losses and about three-quarters of the loans on the books of these banks were to SOEs. Many of these loans should be classified as non-performing. By 1999, three of these SOBs would be insolvent, if assets were marked to market, although all four remain highly liquid because of their dominant share of household deposits in an economy with a high savings rate and few competing assets for household portfolios.

In the mid-1990s, the Chinese authorities engaged in a series of reforms to deal with the bad loans problem culminating in the creation of four asset management companies (AMCs), one for each bank, to take on these bad loans. This paper looks briefly at the international experience with AMCs, focusing on the U.S. Resolution Trust Company upon which the Chinese reform was modeled, and summarizes the experiences of three fast-track transition countries in dealing with bad loans to draw implications for China's program. First, bad loan recovery will be much more difficult in China than in the U.S. due to the extent of the problem, the nature of the assets, and the nascent state of China's capital markets. Second, transition experiences point to the crucial importance of dealing with the flow problem of new bad loans. This incentive problem was handled successfully in Hungary by separating weak clients from banks and privatizing banks to foreign owners as a credible commitment to no further government bailout.

In 1999, the Chinese authorities established four AMCs as temporary institutions to deal with bad loans originated before 1996 that totaled 19\% of 1999 GDP. AMCs are charged with both the disposal of assets and the restructuring of SOEs, with the latter facilitated by debt-equity swaps approved by State Economic and Trade Commission (SETC). They are responsible to three government agencies; in addition to the SETC, these are the Ministry of Finance and the People's Bank of China, the central bank. The 
combination of the direct relationship between an AMC and its parent bank and this shared oversight leaves several unresolved issues. First, AMCs are set up as SOEs so that their governance is beset with traditional problems. Second, AMCs are expected to engage in a broad range of financial activities without the requisite human capital. Third, the incestuous relationship with the parent bank that retains the SOE client makes the flow problem paramount. Fourth, the difficulty of committing credibly to a once-off policy may lead to further default and a serious moral hazard problem.

We offer a modest proposal that transforms the AMCs from temporary institutions to continuing players in China's financial sector and addresses these incentive problems. Since the recognition of bad loans is a dynamic process, we recommend that the entire client relationship, not just the bad assets, be transferred from the parent bank to the AMC. Each of the four large banks will decide which SOEs it wishes to retain as client as which it prefers to transfer to its AMC. This establishes the SOB's full responsibility for the SOEs that it keeps as clients. It also provides the AMC with leverage over the clients whose loans it has inherited since these SOEs will depend on the AMC for their banking needs. In addition to downsizing somewhat the SOBs, this proposal allows the AMCs to develop into viable financial institutions that will compete eventually for commercial business. The skills learned by the staff in working with weak clients in restructuring debts will be useful in future banking activities. Our proposal supports the development and competitiveness of China's banking sector by establishing new domestic financial institutions akin to venture capitalists or investment banks. 


\section{Introduction}

China was the only major economy in East Asia that not only avoided the recent financial crises but also continued to exhibit strong growth. This was attributable mainly to the strengths of the Chinese economy, including the current account surpluses, the dominance of foreign direct investment in capital inflows, the size of foreign exchange reserves and the control of capital account (Huang and Yang 1998). China was fortunate to have controls over the capital account in place when the East Asian financial crises began (Fernald and Babeson 1999). The insulation of the domestic capital market helped to prevent a fatal international attack due to uncertainties of capital flows. However, strong evidence of the fragility of China's banking sector can be found in Bonin (1999), Bonin, Cheng, and Jaffee (1999), Cheng, (1999), and Lardy (1998). Furthermore, gradual liberalization of China's capital account is inevitable with its accession into the WTO.

If financial risk is not eliminated quickly, the probability of a banking crisis will increase. Such a crisis would not only lower the living standards of the Chinese people but also eliminate many of the achievements of economic reform overnight. International experience suggests that cleaning up banking problems is costly, often accounting for 10 to 20 per cent of GDP (Goldstein and Turner 1996; Dziobek and Pazarvasioglu 1997). Existing estimates indicate that the costs for China would be at the upper end of this range, at best ${ }^{2}$ Resolving the bad loan problem is crucial to sustaining growth and continuing reform as the ratio of bank loans to GDP stands at more than $120 \%$.

In any banking system, the bad loans problem consist of a stock component, old debt that is not performing, and a flow component, new lending that may become nonperforming. The two components are linked by the normal client relationship in banking 
and, in some countries, by the government's encouraging or even directing state-owned banks to lend to unprofitable state-owned enterprises (SOEs). ${ }^{-1}$ New lending to a client with non-performing old debt is likely to become a bad loan. Government-encouraged loans to SOEs that are chronic loss-makers are likely to be non-performing. Both aspects must be considered in designing policy for bad loans in China.

The Chinese government has taken a series of measures designed to build a strong banking system including: recapitalization of the state-owned banks (SOBs), adoption of the international standard accounting system, establishment of four asset management companies (AMCs) and introduction of debt-equity swaps as an instrument for dealing with bad debt. The exact policy procedures for dealing with the bad loans are still unfolding, as the transfer of the non-performing loans (NPLs) to the AMCs was completed only recently. Hence, many questions remain to be answered and some opportunities to modify policy remain. Is the current institutional set up of the AMCs efficient? Will the AMCs be able to work out the NPLs as expected? Will asset sale and debt for equity swaps prove feasible? How will the government prevent moral hazard problems from affecting all parties: the enterprises, the banks and the AMCs?

This paper analyzes the bad loan problem of the Chinese banks with an ultimate goal of providing some answers to these questions. The next section explains why financial fragility developed rapidly during the reform period and assesses the seriousness of the bad loan problem. Section 3 discusses the experiences of the Resolution Trust Corporation (RTC) in the United States and bank restructuring policies in three Central European transitional economies with an eye to drawing lessons for the Chinese AMCs. Section 4 characterizes the institutional arrangements for the AMCs and identifies some 
remaining problems. Section 5 presents a suggestion for modifying the current AMC

program. Section 6 concludes with a consideration of the impact of complementary reforms on bank policy.

\section{Growing Financial Fragility}

Financial fragility emerged during the reform period as a result of the evolving triangular relationship among the SOEs, the SOBs and the fiscal system (Huang and Yang 1998). The reform of SOEs was aimed at transforming them into financially viable, independent economic units. To expand enterprises' autonomy and incentives and to strengthen their responsibilities, the government experimented with the responsibility system, the contract system and the share-holding system (Huang et al 1999). To increase further the enterprises' independence, financial relations between the SOEs and the state were redefined through the loans for grants and the tax for profit reforms during the first half of the 1980s. Bank loans replaced free budget grant allocations as the key source of SOEs' capital and tax payments replaced profit remittances as sources of fiscal finance.

The objective of the SOB reform was to build a well functioning two-tier bank system with the central bank responsible for financial supervision and monetary policy and the commercial banks responsible for the allocation of capital. Currently, the four major SOBs account for about 70 per cent of domestic credit and hold over 70 per cent of household deposits (Lardy 1998). Rounding out the financial sector are rural consumer cooperatives holding about $10 \%$ of domestic credits and $20 \%$ of household deposits and urban commercial cooperatives with about $5 \%$ of each. As a group, trust and investment companies (TICs), which are not allowed to take household deposits, had held an 
appreciable share of domestic credit, around 6\%, until recent bankruptcies lowered their market share. No other bank, or group of banks, currently holds any appreciable market share in domestic credits or household deposits although new private banking licenses are increasing. The four large SOBs are to remain under state ownership for the foreseeable future; they are large by international standards when assets are used to measure size. At the end of 1996, the largest, the Industrial and Commercial Bank of China (ICBC), was ranked fifth and all four were among the top fifty of all banks in the world. . $_{\text {Hence, the }}$ big four SOBs dominate a banking sector that is itself the dominant part of the financial sector in China.

The Commercial Bank Law, promulgated in 1995, separated commercial banking and investment banking and set prudential ratios for bank portfolios. The law made banks responsible for their profits and losses but also mandated that they conduct lending according to the needs of the national economy and social development following the direction of the state's industrial policy. The latter directive is often in conflict with the former and indicates that SOBs are not independent from policy lending. Hence, SOBs can not be expected to bear full responsibility for their lending decision. The goal of fiscal reform was for the state to withdraw gradually from direct allocation of capital and to concentrate on supplying public goods. From the mid-1980s, the fiscal system was decentralized to give more incentives to the local governments. In 1994, a new scheme was introduced to specify clearly the division of local-central tax revenues (Brean 1998).

These reforms had clear, but sometimes contradictory, objectives and were implemented gradually and often incompletely. This led to important drawbacks and eventually gave rise to financial fragility. The debt-equity ratio of the SOEs rose 
dramatically from 23 per cent in 1980 to 440 per cent in 1998, following the loan for grant reform. The enterprise reforms succeeded in expanding autonomy and providing incentives but failed to establish a governance system for monitoring and enforcing responsibility. Loss-making SOEs were rarely liquidated and redundant workers were not usually dismissed until very recently. Between 1980 and 1994, enterprise expenditures on social welfare increased by six times and, in the mid-1990s, it was roughly half of the SOEs' total wage bill (Huang et al 1999). Consequently, the profitability of SOEs fell sharply and, from 1996, the consolidated state sector became a net loss-maker. As a result, SOBs were often forced to extend new loans to illiquid SOEs.

The financial deficits of the SOEs had direct fiscal implications. The revenue capacity of the fiscal system declined significantly during the reform period. The share of fiscal revenues to GDP decreased from above 30 per cent in the early 1980s to 12 per cent in the late 1990s (Brean 1998). However, the government could not refrain from intervening in enterprise activities, especially from subsidizing loss-making SOEs. ${ }^{6}$ In doing so, the government sought financial resources from the commercial banks in the form of policy loans, which accounted for about 35 to 40 per cent of total bank loans in the 1990s (Institute of Economics 1998). Projects financed by policy loans usually have high default rates. Bank loans to GDP increased from 50\% in the late 1970s to $120 \%$ in the late 1990s. Clearly, a shift from fiscal financing to bank lending, or quasi-fiscal financing, occurred during this period and the government incurred contingent liabilities for some of the assets on the SOBs' balance sheets.

These institutional weaknesses had adverse impacts on the health of the banking system. The profitability of the SOBs banks declined consistently in the 1990s. If 
uncollected interest payments are excluded from the revenue side of the financial accounts, most SOBs, except the Bank of China, would report financial losses by 1996 and in the following years ( $\mathrm{Li} 1998$ ). At that time, the average capital-adequacy ratio was only 4.4 per cent, which was lower than in 1994 and much lower than that required by China's Commercial Bank Law (Lardy 1998). In 1998, the Chinese government recapitalized the banks to raise their capital-adequacy ratio to above 8 per cent. However, since uncollectable loans are not accounted for properly, capital adequacy ratios are not very meaningful.

Discussions of China's banking problems concentrate on NPLs, although the exact quantification of these is difficult. Chinese authorities do not release official data for confidence reasons. Prior to 1998, Chinese banks used a loan classification system based on actual loan performance that divided NPLs into three types: overdue, doubtful and bad. 7 This approach underestimated NPLs, as it did not include highly risky loans that were still paying interests and were not yet overdue. ${ }^{8}$ The central bank once dictated that SOBs could classify no more than 5 per cent of all of their loans as overdue, no more than 8 per cent as doubtful and no more than 2 per cent as bad (Lardy 1998). Existing estimations suggest that the proportion of the NPLs was likely to have been about 24 per cent (CCER, 1998, and Li, 1998) before the Asian crisis and about 29 per cent (Fan, 1999, and Li, 1998) after the crisis. Such proportions are very high even compared with NPLs in the crisis-affected East Asian economies.

These estimates are supported by SOE survey data found in Yuan (1999) that report non-performing debts owed by the SOEs. In 1995, the proportion of nonperforming debts in Yuan's samples ranged from 19\% in Jiangsu province to almost 43\% 
in Jiln province with ratios for Sichuan and Hunan provinces around $31 \%$. ${ }^{10}$ Bad debts, themselves, were 6 per cent of total debt in 1995, which is similar to the estimate by CCER (1998) for the whole banking sector in 1997. Obviously, the state budget will have to bear most of the cost of bank restructuring and this has important macroeconomic implications. China is regarded as a low debt burden country, with a debt to GDP ratio of 25 per cent, of which about 10 per cent is domestic debt and 15 per cent is external debt. This ratio is significantly lower than the internationally acceptable level for sustainability of 60 per cent (Fan 1999). However, given the low and declining revenue capacity of the fiscal system, the feasibility of accumulating further debt may not be as attractive as the low ratio suggests. More importantly, if unrecoverable bank loans were included, total debt would already account for more than 45 per cent of GDP.

\section{International Experiences with Bad-Debt Workout}

Klingebiel (1999) considers the experiences of several countries in setting up centralized asset management companies both to deal with NPLs and to resolve solvency problems of distressed financial institutions. Two types of agencies are identified: rapid asset disposition agencies and longer term restructuring agencies. Of the seven cases considered, four are in the former category. Of these, only the U.S. Resolution Trust Company (RTC) has been wound up. The other three are still in existence, although they were designed to be temporary government agencies. In two of these three cases, Mexico and the Philippines, Klingebiel concludes that the asset management agencies hid the extent of the bad loan problem and prolonged the effective resolution of the banking crisis. After a brief review of the successful RTC experience in the U. S., we summarize 
the experiences with banking sector reform in three fast-track Central European transition economies. In our opinion, these experiences are more relevant for China than is the U.S. case.

\subsection{The Resolution Trust Company in the United States}

The RTC was set up as a rapid asset disposal agency in 1989 to resolve bad loans from the portfolios of failed Savings and Loan Associations (S\&Ls). ${ }_{\text {As part of a public }}$ agency, the RTC had several objectives: to maximize the net revenues from the sale of transferred assets, to minimizing the impact on local real estate markets and financial markets, and to maximize available and affordable housing for low-income individuals. The assets transferred amounted to $\$ 465$ billion or about $8.5 \%$ of total financial sector assets and approximately $8.5 \%$ of GDP in 1989. For comparison with China, it is important to note that the RTC acquired both performing and non-performing assets and that the level of NPLs reached only $3 \%$ of total banking sector assets at the height of the U.S. crisis. Furthermore, about $50 \%$ of the assets were real estate loans and mortgages while $35 \%$ were cash and other securities. Hence, many of the transferred assets were either good or could be sold quickly through bundling, securitization, and auctions in the deepest capital market in the world.

The RTC was set up as a temporary federal agency intended to operate until 1996 only; it completed its work in 1995 so that the sunset clause was honored. The majority of the senior personnel at the RTC came from the Federal Deposit Insurance Company and, consequently, its staff had experience with the resolution of failed financial institutions. Nonetheless, the RTC relied on private sector contractors to evaluate, manage and sell many of the assets. An effective management structure allowed the RTC to collect 
almost one-third of the assets transferred reducing significantly the amount to be sold. Although the recovery rate on total assets transferred was $86 \%$, the final cost of the RTC's operations amounted to $\$ 88$ billion, which is about $20 \%$ of the total value of assets transferred and over $1.5 \%$ of 1989 GDP.

According to Klingebiel (1999), several unfavorable factors influenced the RTC's operations. First, sporadic government funding increased resolution costs. Second, rapid asset disposal was hampered by inconsistent multiple objectives. On the other hand, several favorable factors were identified. First, the amount of assets transferred was a relatively small percentage of overall financial assets and many of these were performing at the time. Second, the assets could be bundled and securitized for quick sale in deep capital markets. Third, the RTC was able to contract out the disposal of assets to private sector agents having the necessary skills and expertise. As we shall argue below, China's situation makes it unlikely that these favorable factors apply; rather China's reform policy is more likely to fall victim to unfavorable factors.

\subsection{Bank restructuring in Central Europe}

The experiences of the fast-track Central European (CE) countries, i.e., the Czech Republic, Hungary and Poland, with bank insolvency and bad loans provide a list of more don'ts than do's! 12 Of these three countries, the Czech Republic had a financial structure most resembling that of China with a relatively high ratio of bank loans to GDP and market shares of the big four banks of about $70 \%$ for loans and $80 \%$ for deposits. Furthermore, at the beginning of the banking reform in 1990 in then Czechoslovakia, all of the working capital of SOEs was funded by short-term, low-interest, revolving bank credit referred to as TOZ loans. A centralized hospital bank, Konsolidacni Banka (KnB), 
was created for restructuring these loans on commercial terms. All TOZ loans were transferred along with a comparable amount of enterprise deposits from the other banks. However, the SOE clients remained with their parent banks that provided banking services and new loans. In several stages, other loans classified as bad were transferred from the largest Czech banks to $\mathrm{KnB}$ for work out and the government recapitalized the parent banks.

Although considered appropriate at the time, the Czech solution failed to insure the strength of the domestic banking system. Neither the creation of a separate hospital bank for credit obligations extended on non-market terms nor several rounds of cleaning up the banks' balance sheets made the big four Czech banks strong financial pillars. What went wrong? Simply put, the foundations for a strong market-oriented banking sector were not put in place. First, the big banks did not achieve independence from the government as the state-retained majority or near majority stakes in them after these banks participated in voucher privatization. Second, the incentive (flow) problem was not solved as the banks not only retained their clients but they became even more involved with some of them as a result of voucher privatization. In the privatization process, banks through their investment funds took ownership stakes in some of their clients so that the potential arose for a conflict of interest between the bank as an equity holder and the bank as a debt holder. When a mini-currency crisis hit, Czech firms became distressed and the banks' balance sheets suffered. Interestingly, the Czech government's protectionist policy had allowed domestic banks to maintain high spreads and, hence, earn reasonable profit margins. Even in this environment in which banks could self-capitalize, the bad loans problem was not resolved because soft lending 
practices were continued. The large Czech banks are currently in need of another round of significant recapitalization before they can be sold to foreign investors. Estimates now indicate that the total cost of bank restructuring in the Czech Republic may be about 30\% of GDP, making the Czech clean-up the highest cost restructuring program in any transition economy to date.

By contrast, Hungary pursued a policy of privatizing state banks by selling controlling shares to strategic foreign investors as rapidly as possible. Such sales required recapitalization of the banks to make the combination of current net worth and franchise value attractive to a foreign investor. Two major and several minor recapitalizations of its domestic banks earned Hungary the dubious distinction as the country most oblivious to moral hazard. The first major recapitalization was insufficient both because the instruments used were not sufficiently liquid or financially attractive and because the recapitalized banks were still servicing bad clients. A second major recapitalization, using market-type instruments, was ultimately successful because it was followed closely by privatization to independent, foreign, owners. This combined recapitalization and privatization strategy left Hungary with the strongest banking sector of all transition countries.

The Hungarian experience points to the importance of achieving independent governance both from the state and from undesirable clients. Of more importance than inherited bad loans to the forward-looking operations of the bank are inherited bad clients. The Hungarian bank with the most exposure to loss-making SOEs was Magyar Hitel Bank (MHB). Prior to searching for a strategic foreign investor but after recapitalization, MHB's loan portfolio was divided into good and bad assets. The bad 
loans along with these clients' deposits were separated from the good part of MHB and a department was set up to work with these clients in an attempt to recover some portion of the bad loans. Only the good bank was privatized; this transaction attracted a strategic foreign investor who increased subsequently the bank's capital.

The Polish experience indicates the inappropriateness of making banks responsible for enterprise restructuring. The World Bank supported a program of bankled enterprise restructuring based on the notion that the major bank creditor had sufficient information about their clients either to promote restructuring or to decide to liquidate large SOEs. Financial restructuring dominated bankruptcy as the preferred option (Gray and Holle, 1996). The main instrument used to restructure loans was the debt-equity swap; this option was chosen disproportionately by the weaker banks. Hence, weak banks with no expertise in restructuring large companies wound up taking ownership stakes in their weak clients. Furthermore, new bank credit was provided to ailing enterprises in about a third of the cases surveyed by Gray and Holle (1996). In a case study of one Polish bank, Bonin and Leven (2000) find that new credit extended to three large military-industrial clients in the program exceeded the total amount of bank recapitalization and left the bank with more, rather than less, exposure to these clients after financial restructuring. As in the Czech Republic, Poland's program strengthened, rather than severed, the ties between banks and their undesirable clients. Hence, the Polish program provided breathing room for weak SOEs to postpone painful restructuring and, in doing so, it underscored the importance of banks divesting themselves of their non-viable clients. 


\subsection{Implications for China}

How can the policymakers who are promoting banking reform in China use these international experiences? Obviously, it is unreasonable to expect China to follow Hungary's example and sell majority stakes in its SOBs to strategic foreign investors. If resolving the bad loan problem and promoting independent, sound commercial lending decisions in state-owned banks are taken as the medium-term objectives of Chinese banking reform, several lessons can be drawn.

To begin with, four important differences between the Chinese and U.S. situations make the experiences of other transition countries more relevant than that of the U.S. to China. First, the RTC was established to deal with mainly real estate loans from S\&Ls that had been shut down or merged with other banks. Hence, the flow issue of new bad loans from the originating financial institutions was not a problem in the U.S. In China, the loans transferred to AMCs were made by SOBs to their SOE clients. Both banks and creditors continue to have ongoing financial relations with each other. Hence, the flow

problem of preventing new bad loans becomes a prominent concern. Second, the bad assets taken over by the RTC were eventually sold in the deep and sophisticated capital markets of the U.S. China's capital markets are thin and segmented; thus, they resemble capital markets in transition economies so that it will be difficult to dispose of bad assets rapidly. Third, in the U.S., and in the Czech Republic initially, a large portion of the loans transferred were performing, good assets. In China, only NPLs will be transferred so that all such assets will require work out. Taking into consideration the thin asset markets in China, such loan work out will likely rely more heavily on debt/equity swaps than on asset sales. Fourth, the RTC used outside consultants extensively to manage and dispose 
of the bad assets. In China, the availability of outside expertise is limited so that emphasis must be placed on attracting and retaining competent staff for AMCs.

The second crucial point is that preventing the flow of new bad loans is more important than getting rid of the stock of existing bad loans. The Czech experience indicates that transferring bad loans from all banks to a single centralized hospital bank does not solve the incentive problem if the client remains attached to the original SOB. Experience in Poland indicates that, while banks may have the information to deal with problem clients, they do not often have the expertise and incentives to do so. The Hungarian experience illustrates the wisdom of separating bad clients from banks that are being restructured and recapitalized. This is an important lesson for China in its reform of the banking sector.

A third lesson is that attention must be paid to the organizational structure of the AMCs. One drawback in the design of the RTC was the inclusion of social concerns among its multiple objectives. In China, the AMCs are centralized state-owned organizations. As the experiences in the transition economies validate, state-owned financial institutions have their own governance problems. The experience in Poland indicates that, although the state-owned parent banks may have had the necessary information to restructure financially their problem clients, they were not the best agents to promote the business restructuring of SOEs. Hence, internal incentives must be designed carefully to take account of the skills and human capital of the employees and also to address the likely principal-agent incentive problems in the SOE organizational structure. 
A final lesson is that, although privatizing its SOBs by selling them to foreign investors is not a strategy that China can take from the Hungarian experience, the Hungarian government's credible commitment to no further bank bailouts is a fundamental lesson. From the experiences of the three transition countries, stemming the creation of new bad loans by making a credible commitment to a once-off government recapitalization of the banks and, thus, leaving the banks responsible for all future loans is crucial to the success of banking reform policy. The failure to do so cost the Czech Republic both time and fiscal resources. Whether or not a credible commitment to no future bank recapitalization is possible when the four large and dominant banks continue to be state-owned is the critical problem with which China must grapple.

\section{Asset Management Companies}

The Chinese government began to address the bad loan problem in 1994 with the creation of three policy banks, the Long-term Development and Credit Bank, the Agricultural Development Bank, and the Import-Export Bank. The policy banks are not allowed to take household deposits but, unlike SOBs, they may hold equity stakes in companies. Therefore, according to their license, they resemble investment banks. These banks were created for the purpose of separating policy lending from commercial lending and leaving the latter to the four dominant SOBs. However, policy banks have been involved mainly in longer term infrastructure financing while the SOBs have maintained their relationships with their SOE clients. Hence, from 1996 onward, the government set aside each year a large fund, consisting of RMB40 billion in 1998, to write-off the bad debts of SOBs. 
Between April and October in 1999, China established four AMCs, each of which was associated with one of the four large SOBs, i.e., Cinda (CBC), Huarong (ICBC), Orient (BOC) and Great Wall (ABC). Each received RMB10 billion from the state budget as registration capital to cover current operating expenses. The AMCs are set up to operate for ten years so that, like the RTC, they have sunset provisions. However, unlike in the U.S., the government is creating four separate centralized agencies rather than a single centralized loan workout agency. Of crucial concern for proper incentives is the fact that each major SOB will have its own AMC. Such an arrangement could lead to the expectation that a parent bank can continue to dump bad loans with its AMC offspring.

Together the AMCs are intended to deal with RMB1.3 trillion NPLs, which is about 19 percent of the total loans of the SOBs and 16 percent of 1999 GDP (Li, 2000). Even using conservative estimates, the magnitude of the work out in China as a percentage of GDP is significantly higher than in U.S. For example, assume that no more than half of the assets transferred to the RTC was non-performing and that NPLs are $25 \%$ of GDP in China. Then, transferred assets to GDP in China would be about three times that same ratio in the U.S. and half of the stock of bad debt would still be left with the parent Chinese banks.

In fact, the loans eligible to be transferred had to have been originated before 1996 under the presumption that loans made after that date are the bank's own responsibility because of the Commercial Bank Law. Aside from the conflicting objectives in this Act, the origination date of a loan to a client with whom a bank has a continuing relationship is often not a good indication of the bank's exposure to that client. Penalties and interest arrears continue to accumulate when the loan is not serviced. More importantly, the plan 
is designed to deal only with the stock of bad loans at a certain date and it ignores entirely the flow problem.

\subsection{Operation of the AMCs}

In April 1999, the Chinese government established the Cinda Asset Management Company (Cinda) to take over bad loans from CBC. Beginning in September 1999, NPLs were transferred to Cinda for workout and recovery. The intent was to remove a portion only of the NPLs from the balance sheet of the parent bank, CBC, and place them with Cinda, which takes responsibility for their workout and recovery. Cinda is expected to collect what it can or repackage the loans and sell them at discounted value on secondary markets. The basic premise is that financial restructuring of the SOEs is necessary to make them economically viable. Reducing the debt burden is intended to promote their profitability. To facilitate a reorganization of their capital structure, Cinda is encouraged to swap bad debt for equity in some large SOEs that are designated by the government.

The transfer of NPLs from parent banks to AMCs involves an exchange at the face value of the loans; thus, the parent banks were compensated fully for all transferred loans. Two methods were used. The first was to transfer some central bank lending from the parent banks to the AMCs at an interest rate of $2.25 \%$; this method accounted for about 40 per cent of the value of the transferred NPLs. The second was for the parent banks to purchase bonds issued by the AMC, guaranteed by the Ministry of Finance, and paying interest at about $2.5 \%$; this method accounted for about 60 per cent of the value of the transferred NPLs. Obviously, the first approach takes both bad assets (NPLs) and liabilities (Central Bank lending) from the parent bank's balance sheet and thus downsizes, to some extent, the SOB. The second approach supports bad assets (NPLs) by 
allowing the AMC to issue liabilities (government guaranteed bonds). Hence, the resulting hole on the SOB's balance sheet, created by the transferred NPLs, is filled.

AMCs are temporary financial institutions with multiple roles to play during their ten-year lifespan. They will operate as both rapid asset disposal and SOE restructuring agencies; the latter involves both financial and operational restructuring. Thus, Chinese AMCs will by hybrids of the two types identified by Klingebiel from international experiences. As restructuring agencies, they will play the role of turnaround managers. Because of the lack of investment banks and venture capitalists in China, AMCs are likely to perform a host of tasks required to restructure SOEs and promote their eventual financial viability.

Organizationally, AMCs are structured as SOEs under the oversight and control of three government agencies. First, the Ministry of Finance provided AMCs with their initial capital and will bear the consequences of their operation. If the AMCs cannot dispose of all transferred NPLs, the Ministry of Finance will either take over the nominal equity (guaranteed bonds) or write off the bad debts directly. Second, the supervision of AMCs is the responsibility of the central bank, i.e., the People's Bank of China (PBOC). The main reason that China is establishing the AMCs as distinct organizations separate from their parent banks is that current regulations prohibit commercial banks from engaging in investment banking activities. However, the combination of close ties between AMCs and their parent banks and a shared responsibility for the operations of AMCs between the Ministry of Finance, in its financing role, and the PBOC, in its supervisory role, is likely to invite moral hazard problems. Finally, the State Economic and Trade Commission (SETC) determines the allowable debt/equity swaps for AMCs so 
that the government may pursue its industrial policy through the AMCs. Having three

government agencies involved in their governance, AMCs can be expected to pursue multiple, and often conflicting, objectives.

\subsection{Still unsolved problems}

The first problem is that, although AMCs are new financial institutions, they are structured organizationally as SOEs. Although some AMCs have devised incentive schemes to stimulate employees' efforts, it is unclear how these will be sufficient to overcome the regulations. More likely, the traditional problems associated with SOEs in China, e.g., shirking and corruption, will plague the AMCs. Without more independence from government agencies, AMCs are also likely to have their activities influenced significantly by government policy.

The second problem is that, although the AMCs are expected to engage in a broad range of financial activities, e.g., loan recovery, venture capital activities, strategic consulting and investment banking, their employees lack the requisite skills for doing so. Employees transferred from parent banks will not be trained to fulfill these tasks. After more than a year of operation, Cinda suffers from two labor problems, namely, redundant workers and the lack of necessary skills in its labor force. Unfortunately, unlike the RTC in the U.S., the AMCs in China do not have the opportunity to hire specialized agencies to provide the missing skills.

A third crucial concern is the moral hazard problem due to the current one-to-one relationship between a parent bank and an AMC. Although obviously helpful for information sharing and other collaboration, such as working out small NPLs, this connection fosters collusive behavior and inhibits competition. Under the current 
arrangements, it is likely that the parent bank will perceive the AMC to be an outlet to which it can transfer more NPLs in the future. To the extent that the government can not make a credible commitment that the current transfer is a once-off policy, the SOB will treat its AMC as a government agency that implicitly insures its lending activity. Hence, the SOB will be lax both in refusing local government intervention to make new loans on a non-commercial basis and in managing the risk of its commercial portfolio.

The final problem is related to the possibility of strategic behavior by SOEs if the government can not commit credibly to a once-off policy. The SOBs are concerned about widespread loan defaulting because of the new instrument of debt-equity swaps available to AMCs. Although the objective of this reform tool is to improve the capital structure of debt-burdened SOEs, the new instrument may actually encourage even profitable SOEs to stop paying interests on the bank loans so that they too qualify for debt relief. If this happens, the consequences for China would be beyond measure.

If these problems are not resolved, existing NPLs will not be dealt with effectively but, more importantly, new NPLs will be encouraged through soft lending by the SOBs. AMCs will be forced to take on more NPLs over time as the government will recapitalize the SOBs again and again. Such a vicious cycle will entrench moral hazard problems and guarantee continuing deterioration of the Chinese banking assets.

\section{A Modest Proposal}

The establishment of AMCs in China provides the potential for putting in place a solid foundation upon which a strong reformed banking system can be built. However, the current policy suffers from a crucial flaw, namely, the inability of the government to 
make a credible commitment to avoid transferring new NPLs to the AMCs in the future. The true extent of the bad loan problem in China is not known. Identification of bad loans is not trivial in any banking system. The necessary information to distinguish a good from a bad loan is imbedded at the branch level, oftentimes with the responsible loan officer. Even in developed banking sectors, old loans may be rolled over and new lending provided to capitalize interest arrears and maintain a loan as performing for a preferred client. Similar strategies have been applied to loans to SOEs in other transition economies. ${ }^{13}$ The identification problem is magnified in China because the standard international loan classification system has been adopted only recently.

As a policy principle, proposals to resolve the stock component of bad loans must take full account of the flow problem of new bank lending to bad clients; here incentive issues are paramount. The dynamic evolution of the stock of NPLs in other transition economies consists of both gradual recognition and continued soft lending to loss-making clients, i.e., making new bad loans. The former is related to unrevealed information due to an unwillingness to disclose the true nature of client loans because of internal incentives within the bank and to uncertainty about the ability of a client to repay a loan because of the overall economic environment in which the client operates. In contrast, the latter is solely an incentive problem and is caused by the link between the bank and its longstanding client. Any policy that strengthens this link exacerbates the flow problem. The explicit or implicit backstop support of the government for SOEs promotes the expectation that the government guarantees any loan to an SOE. For this reason, it is well understood that a government bailout to recapitalize a bank that has a stock of old bad 
debt should be a credible once-off policy. In practice, however, the convolution of information and incentive issues makes this policy principle difficult to follow.

Resolving the bad loan problem in China rests on two key principles that allow the government to make a credible commitment to a once-off bank recapitalization policy and, hence, avoid the moral hazard problem of encouraging new bad loans. First, SOBs must become independent in decision-making from both the state and their bad clients. Independent bank governance turned out to be more elusive than expected in the transition countries; it was often inhibited both by policies designed to deal with bad loans and by policies designed to promote enterprise restructuring through bank involvement. Second, AMCs should be allowed to develop into financial institutions that will eventually provide competition for the commercial business of the big four SOBs. In the transition economies, the entry of new undercapitalized commercial banks did not promote effective competition; rather it led to systemic instability. Allowing foreign bank penetration turned out to be an effective means to encouraging such competition; however, this avenue is not open wide enough in China at present. Hence, effective competition must be developed from within and AMCs can play a role in achieving this goal. Finally, the government should broaden the possibilities for privatization and encourage the participation of a wider group of buyers. What are now thin capital markets in China need to be deepened and broadened to facilitate the eventual disposal of assets by the AMCs.

Since the separation of clients from banks was the key to solving the flow problem in other transition countries, severing relationships between SOBs and weak SOEs should be an important component of the Chinese reform program. Our modest 
proposal is to designate a review period during which the lead parent bank, i.e., the SOB with the largest exposure to any particular client, can decide which of its clients it wishes to shed. The review period should not be overly long to avoid providing the SOB with disincentives to monitor properly its current assets. All loans to clients so designated should be transferred to the lead bank's AMC along with these clients' deposits. In essence, not only should old bad loans be transferred to the AMC, as has been the current practice, but all of the SOEs banking business should be transferred to an AMC. By transferring the client and not just a portion of its bad loans to the AMC, the AMC becomes the sole banker for SOEs designated by their lead bank as problematic. Hence, this policy achieves the dual objective of making the parent bank independent from undesirable clients and holding the SOB accountable for loans to the SOEs that it retains as viable clients since the bank has the option of transferring problematic clients to an AMC.

This proposal also provides the AMC with leverage over the SOEs whose loans it is attempting to recover, as the SOE will be beholden to the AMC for any future financing. The decision to provide new loans should be based on an assessment of the future viability and profitability of the SOE with an eye toward recovering eventually some of the old bad debt. Hence, the AMC becomes an ongoing financial institution focused on restructuring SOEs rather than simply a temporary loan collection agency. Current legislation does not permit AMCs to take deposits so that changes in their charters are required if this proposal is to be implemented. We recommend that AMCs be allowed to take commercial deposits only, and not household deposits, so that their revised charter would resemble that of an investment bank. Nevertheless, the activity of 
an AMC will be different from that of a policy bank. The AMC will make new loans based on its assessment of the eventual economic viability of an SOE. Hence, AMCs would determine which SOEs to restructure and which to wind down. Policy banks would be left to deal with long-term infrastructure and development projects.

In addition to severing the relationship between weak SOEs and parent SOBs, this modification of the Chinese reform proposal changes the character of the AMCs. The AMC is no longer a temporary collection agency created only to work out bad loans; rather it is a new financial institution given the immediate task of restructuring viable SOEs and supporting financially the resulting businesses. With this change, the AMC becomes more of a restructuring agency than a rapid loan disposal agency. Recruitment of talented people to the AMC will be easier if it is viewed as an ongoing financial institution rather than simply as a loan collection agency that intends to close shop after resolving the existing NPLs. ${ }^{14}$ The skills learned by the staff from dealing with enterprise restructuring should be transferable to venture capital and investment bank activities in the longer term leaving the successful AMCs with an important role to play in China's evolving financial markets. 


\section{Conclusion: Complementary Reforms}

The establishment of AMCs provides a unique opportunity for Chinese policymakers to construct new financial organizations that can provide competition for the big four SOBs. By transferring the entire client relationships from parent banks to AMCs, the SOBs are downsized somewhat and the AMCs have a client base on which to build commercial business eventually. The ten-year proposed life span of the AMC could be converted into a transition period during which the AMC would receive financial support from the government for its enterprise restructuring and winding down activities. After this period, the AMCs would become financially independent from the government and continue as investment banks. This proposal begins to fill out the gaps in the institutional spectrum of Chinese banking.

The organizational structure of the AMC must be redesigned so that it is not an SOE. To encourage the collection of revenues and to punish nonperformance and corruption, a penalty-incentive scheme for employees must be designed. Furthermore, AMCs must have the flexibility to recruit and dismiss employees without the constraints imposed by labor laws on SOEs. AMCs should be allowed to contract with specialized agencies, including foreign agencies, to assist in handling situations that are beyond the capacity of their own staff. However, the staff of the AMCs should also be given incentives to develop the necessary skills to manage assets efficiently and to restructure SOEs to bring new, rejuvenated companies to the capital market. In this view, the AMCs would be training grounds for a cadre of domestic staff to acquire the requisite financial skills to further the development of the Chinese capital market. Finally, to promote 
effective competition among AMCs, the AMC must be independent both from its parent bank and from direct control by government agencies.

To address the problem of insufficient opportunities to dispose of assets on secondary markets, the government should open up capital markets. The capital markets in China are currently very small and thin so that recovery on secondary markets is likely to take a significant amount of time. The potential buyers of these assets include private corporate and foreign strategic investors. However, to attract these investors, privatization policy towards SOEs must become more flexible. Their involvement will help the AMCs dispose of their assets more quickly and also provide an important impetus to SOE reform. In the longer term, gradual privatization of the SOBs themselves should occur. Such policies require a more decisive approach to ownership reform of the state sector at the highest levels of the government.

As a complementary policy, the development of sound banking regulation and effective prudential supervision is necessary to impose the proper incentive structure on the SOBs. From a regulatory perspective, the reform must go beyond legislation requiring banks to adopt the standard five-category loan classification system used internationally to promote the proper recognition of problem loans. The experiences in Hungary and the Czech Republic make clear that legislation is not sufficient. The information necessary to ferret out improper behavior is difficult to obtain, especially when coalitions form in whose self-interest it is to keep this information hidden. Attention must be paid to the incentives of bank decision-makers if the actual quality of the loan portfolios is to be revealed. Since banking is a relational activity, bank officers will protect a client with whom they wish to continue to do business. 
At the end of last year, the PBOC inspected fifty branches of SOBs having a large increase in bad loans. Dozens of managers, including two senior officials at Beijing branches of ICBC, were dismissed for incompetence and mismanagement (Financial Times, March 22, 1999). The intent was to change the behavior of managers who had built local fiefdoms and felt secure in their positions because it was rare to be sacked for incompetence. Furthermore, these bank managers were able to maintain good relations with local government authorities because of their support of local SOEs. This policy is a step in the right direction as penalties are an important component of supervision. However, a more comprehensive development of supervisory capabilities and selfenforcing regulation should follow. The current policy discourages lending because bank officials have insufficient incentives to make loans due to the draconian penalties imposed for bad loans. A more balanced approach to the design of internal incentives is required to promote prudent and self-enforcing regulatory practice.

To resolve completely the NPL problem, both old and new, requires reform strategies that go beyond considerations of the AMCs and the SOBs. Because of the triangularization of the bad loan problem, a successful reform of the fiscal system, the restructuring of the SOEs, and the creation of independent SOBs are all interdependent. The regional reorganization and proper functioning of the central bank is critical because of the regulatory role it plays in the financial system. The reform of fiscal financing is crucial to bring to a halt soft lending practices and, thus, to removing the responsibilities for financing the government's industrial policy from the commercial banking sector. Although these are important policy issues, any in-depth consideration of such complementary reforms is beyond the scope of the current paper. 


\section{REFERENCES}

Ábel, István and John P. Bonin, 1994, "State Desertion and Credit Market Failure in the Hungarian Transition," Acta Oeconomica, 46(1-2): 97-112.

Bonin, John P., 1999, “Banking Reform in China: Gradually Strengthening Pillar or Fragile Reed?," William Davidson Institute Working Paper \#234.

Bonin, John P., Kálmán Mizsei, István Székely and Paul Wachtel, 1998, Banking In Transition Economies: Developing Market Oriented Banking Sectors in Eastern Europe, Edward Elgar Publishing Limited: Cornwall, U.K.

Bonin, John P., Cheng, Hang-Sheng and Jaffee, Dwight M., 1999, “Bad Loans and Banking Reform in China," working paper, September.

Bonin, John P. and Leven, Bozena, 2000, “Can Banks Promote Enterprise Restructuring?: Evidence From a Polish Bank’s Experience,” William Davidson Institute Working Paper \#294.

Brean, D. J.S. (ed.), 1998, Taxation in Modern China, Routledge: New York.

CCER (China Center for Economic Research), 1998, "Seeking effective policy combination under multi economic objectives: Analyses of China's macroeconomic situation in 1998 and some recommendations", Economic Research Journal [Jingji Yanjiu], 4(April): 1-10.

Chang, Gene H., 1998, “The Chinese economy in the Asian financial crisis: The prospect of the stability of RMB”, Harvard Institute for International Development Discussion Papers, No. 669. 
Cheng, Hang-Sheng, 1999, "Can China Achieve Bank Marketization Without Bank Privatization?," in Harvey Rosenblum ed., "Bank Privatization," Conference Proceedings of a Policy Research Workshop Held at the World Bank.

Dai, Xianglong, 1998, “China's central bank governor on financial situation”, People's Daily [Renmin Ribao], March 7, 1998, Beijing.

Dong, F., 1999, “Carefully nurturing security markets,” People’s Daily (Overseas Edition), July 3, 1999.

Dorn, J.A., "China's financial future", ChinaOnLine, (http://www.chinaonline.com/commentary_analysis/c9091360e.asp)

Dornbusch, R. and Givazzi, F., 1999, "Heading off China’s financial crisis”, unpublished paper, Department of Economics, Massachusetts Institute of Technology, Cambridge, M.A.

Dziobek, C. and Pazarbasoglu, C., 1997, "Lessons from systemic banking restructuring: A survey of 24 countries", International Monetary Fund Working Paper No. 97/161, Washington D.C.

Fan, G., 1999, ‘On overall debt burden’, Economic Research Journal, 5:1-9.

Fernald, J.G. and Babson, O.D., 1999, "Why has China survived the Asia crisis so well? What risks remain?,” International Finance Discussion Papers, Board of Governors of the Federal Reserve System, Washington DC.

Garnaut, R., 1998, "Economic lessons," East Asia in Crisis: from being a miracle to needing one? Chapter 21 in R. Mcleod and R. Garnaut (eds), Routledge, London. Gray, Cheryl W. and Holle, Arnold, 1996, "Bank-led restructuring in Poland: the conciliation process in action," Economics of Transition, 4( 2): 349-370. 
Gray, Cheryl W. and Holle, Arnold, 1997, "Bank-led restructuring in Poland (II): bankruptcy and its alternatives," Economics of Transition, 5(1): 25-44.

Goldstein, M. and Turner, P., 1996, "Banking crisis in emerging economies: Origins and policy options,” BIS Economic Papers No. 46, Monetary and Economic Department, Bank for International Settlements, Basle.

Huang, Yiping, and Yang, Yongzheng, 1998, “China’s financial fragility and policy responses," Asian-Pacific Economic Literature, 13(2): 1-13.

Huang, Yiping, Woo, Wing Thye, and Duncan, R., 1999, "Understanding the decline of China's state sector," MOCT-MOST: Economic Policy in Transitional Economies, 9(1): $1-15$.

Institute of Economics, Chinese Academy of Social Sciences, 1998, "Aggregate trend, financial risk and external shocks: Analyses of the current Chinese macroeconomic situation," Economic Research Journal [Jingji Yanjiu], 3(March): 3-14.

Klingebiel, Daniela, 1999, “The Use of Asset Management Companies in the Resolution of Banking Crises: Cross-Country Experiences,” World Bank Working Paper, April, 1999

Lardy, Nicholas R., 1998, China's Unfinished Economic Revolution, Washington D.C.: Brookings Institution and Institute for International Economics.

Li, Wenhong, 2000, "Dealing with Problem Banks in the Context of Bank Restructuring in China", Master Thesis submitted to the National Centre for Development Studies, Australian National University, Canberra. 
Li, Xinxin, 1998, “Looking at China's potential financial risks from the East Asian financial crisis: Analyses of the assets operation of the state-owned commercial banks," Reform, 3(March): 31-39 and 86.

Li, Yang, 1997, "Capital flows of the Chinese economy in the process of opening up." Economic Research Journal, 2(February): 14-24.

Pomfret, J., 1999, “China set to tackle economic woes,” Washington Post Foreign Service, Saturday January 16, 1999, Page A21.

Qian, Yingyi, 1994, "Financial system reform in China: Lessons from Japan's main bank system," Aoki and Patrick, eds. The Japanese main bank system: Its relevance for developing and transforming economies, Oxford and New York: Oxford University Press: 552-91.

Research Group for China’s Financial System Reform (RGCFSR), 1997, “A tracking study of the Chinese financial system reform," Reform [Gaige], 3: 64-75, and 4: 83-98.

Sicular, Terry, 1998, "Capital flight and foreign investment: Two tales from China and Russia," The World Economy, 21(5): 589-602.

SSB (State Statistical Bureau of China), various years, China Statistical Yearbook, Beijing: China Statistics Publishing House.

Woo, Wing Thye, 1999, “China's battle for stability amidst the regional crisis," paper presented at the Davos Conference of World Economic Forum, January 1999.

Xie, Ping, 1992, “An analysis of China's financial assets,” Economic Research Journal [Jingji Yanjiu], 11(November). 
Yi, Gang, 1996, “An analysis of China's financial assets structure and its policy implications" ['Zhongguo Jinrong Zichan Fenxi Jiqi Zhengce Hanyi'], Working Paper Series, No. 1996004, November 1996, China Center for Economic Research, Beijing.

Yuan, Gangming, 1999, “Bad Debts of China’s State-owned Enterprises,” Paper presented at the $11^{\text {th }}$ Annual Conference of the Association for Chinese Economic Studies, July 15-16, 1999, Melbourne.

Zhang, Jie, 1998, The Structure and Evolution of China's Financial System, Taiyuan: Shanxi Economic Publishing House. 
${ }^{1}$ Recent studies suggest that, even in the presence of the capital account controls, capital outflows through informal channels have been significant (Sicular 1998).

${ }^{2}$ See, for instances, Australian Financial Review (August 19, 1999) and Dornbusch and Givazzi (1999).

${ }^{3}$ For comparison, credit to the non-financial sector as a percentage of GDP was $20 \%$ in Poland, $23 \%$ in Hungary, and 53\% in the Czech Republic in 1995 (OECD, 1997, p.81).

${ }^{4}$ At the National People's Congress in March, Zhu Rongji called for an attack on "the unprecedented and grim" economic environment and reminded state banks of their "political" responsibilities to lend to moneylosing enterprises (The Economist, March 13, 1999).

${ }^{5}$ The other large banks are the Agricultural Bank of China (ABC), the Bank of China (BOC) and the Construction Bank of China (CBC). For comparison, only one of the Polish banks ranks amongst the 100 largest banks in Europe and this is a consolidated financial group.

${ }^{6}$ Direct government subsidies to loss making SOEs were relatively stable throughout the 1980s and 1990s, ranging between RMB33 billion and RMB60 billion per year (Perkins 1999).

${ }^{7}$ Loans overdue were defined as loans not repaid when due or not repaid after the due date has extended. Doubtful loans were defined as loans that have been overdue for more than two years or operation of the projects has been stopped. Bad debts were defined as loans that have not been repaid after the enterprises' bankruptcy or liquidation.

${ }^{8}$ Lardy (1998) suggests other reasons why the NPL problem might be underestimated in the old Chinese system. Bank accounting and auditing practices in China have severe shortcomings; external auditing was not a common practice until very recently. Apart from NPLs, banks often have substantial non-performing assets that are not reported. Finally, because the data on NPLs exclude interbank and trust lending as well as credit that is concealed in balance sheets as other items, they may underestimate significantly the total amount of non-performing assets of China's largest banks. 
${ }^{9}$ The pre-crisis proportion of NPLs in these countries were as follows: Thailand: 15 per cent, South Korea: 16 per cent, and Indonesia: 12 per cent. China's proportions are similar to those in the post-crisis situations in these countries, e.g., Thailand: 27 per cent, Indonesia: 33 per cent, and Korea: 25 per cent.

${ }^{10}$ SOEs in Jiangsu province had the lowest numbers, partly because of their better positions in the market and partly because of their lower concentration in heavy industries. The problems of the SOEs in Sichuan and Hunan provinces were quite bad as most of these firms were military-related and relocated to their remote locations in the 1960s. The worst situation was in Jiln province, a traditional heavy industry base in China.

${ }^{11}$ This section relies heavily on tables in Klingebiel (1999) for information about the RTC experience. The first table begins on p.28 and the others are found in the Appendix.

${ }^{12}$ For a more detailed discussion of the bad loan problem in CE, see Ábel and Bonin (1994) and Bonin, Mizsei, Székely, and Wachtel (1998). Some of the material in this section and in the sections to follow also appears in Bonin, Cheng, and Jaffee (1999).

${ }^{13}$ When a strict trigger was applied to the Bankruptcy Act in Hungary forcing any company with any loan of any amount that is overdue for 90 days to file for bankruptcy, several large banks began granting 89-day loans to preferred clients.

${ }^{14}$ A similar institutional issue existed for the Treuhandanstalt, an agency established to privatize SOEs in the former GDR. The staff members used their experiences in Germany to set up a consulting agency to advice privatizations in other transition economies. 


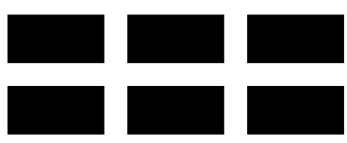

THE WILLIAM DAVIDSON INSTITUTE

AT THE UNIVERSITY OF MICHIGAN BUSINESSSCHOOL

\section{DAVIDSON INSTITUTE WORKING PAPER SERIES - Most Recent Papers}

The entire Working Paper Series is available at: www.wdi.bus.umich.edu

CURRENT AS OF $1 / 22 / 01$

\begin{tabular}{|c|c|c|}
\hline Publication & Authors & Date \\
\hline No. 357 Dealing with the Bad Loans of the Chinese Banks & John P. Bonin and Yiping Huang & Jan. 2001 \\
\hline No. 356 Retail Banking in Hungary: A Foreign Affair? & John P. Bonin and István Ábel & Dec. 2000 \\
\hline $\begin{array}{l}\text { No. } 355 \text { Optimal Speed of Transition: Micro Evidence from the Czech } \\
\text { Republic }\end{array}$ & $\begin{array}{l}\text { Stepan Jurajda and Katherine } \\
\text { Terrell }\end{array}$ & Dec. 2000 \\
\hline No. 354 Political Instability and Growth in Dictatorships & $\begin{array}{l}\text { Jody Overland, Kenneth L. } \\
\text { Simons and Michael Spagat }\end{array}$ & Nov. 2000 \\
\hline No. 353 Disintegration and Trade & Jarko Fidrmuc and Jan Fidrmuc & Nov. 2000 \\
\hline $\begin{array}{l}\text { No. } 352 \text { Social Capital and Entrepreneurial Performance in Russia: A } \\
\text { Panel Study }\end{array}$ & Bat Batjargal & Dec. 2000 \\
\hline $\begin{array}{l}\text { No. 351 Entrepreneurial Versatility, Resources and Firm Performance in } \\
\text { Russia: A Panel Study }\end{array}$ & Bat Batjargal & Dec. 2000 \\
\hline $\begin{array}{l}\text { No. } 350 \text { The Dynamics of Entrepreneurial Networks in a Transitional } \\
\text { Economy: The Case of Russia }\end{array}$ & Bat Batjargal & Dec. 2000 \\
\hline $\begin{array}{l}\text { No. } 349 \text { R\&D and Technology Spillovers via FDI: Innovation and } \\
\text { Absorptive Capacity }\end{array}$ & Yuko Kinoshita & Nov. 2000 \\
\hline $\begin{array}{l}\text { No. } 348 \text { Microeconomic aspects of Economic Growth in Eastern } \\
\text { Europe and the Former Soviet Union, } 1950-2000\end{array}$ & Sergei Guriev and Barry W. Ickes & Nov. 2000 \\
\hline $\begin{array}{l}\text { No. } 347 \text { Effective versus Statutory Taxation: Measuring Effective Tax } \\
\text { Administration in Transition Economies }\end{array}$ & $\begin{array}{l}\text { Mark E. Schaffer and Gerard } \\
\text { Turley }\end{array}$ & Nov. 2000 \\
\hline $\begin{array}{l}\text { No. } 346 \text { Objectives and Constraints of Entrepreneurs: Evidence from } \\
\text { Small and Medium Size Enterprises in Russia and Bulgaria }\end{array}$ & $\begin{array}{l}\text { Francesca Pissarides, Miroslav } \\
\text { Singer and Jan Svejnar }\end{array}$ & Oct. 2000 \\
\hline No. 345 Corruption and Anticorruption in the Czech Republic & $\begin{array}{l}\text { Lubomír Lízal and Evžen } \\
\text { Kočenda }\end{array}$ & Oct. 2000 \\
\hline ct Foreign Investment on Dom & Jozef Konings & Oct. 2000 \\
\hline No. 343 On the Identification of Relative Wage Rigidity Dynamics & Patrick A. Puhani & Oct. 2000 \\
\hline $\begin{array}{l}\text { No. } 342 \text { The Determinants of Foreign Direct Investment in Transition } \\
\text { Economies }\end{array}$ & Alan A. Bevan and Saul Estrin & Oct. 2000 \\
\hline No. 341 The Global Spread of Stock Exchanges, 1980-1998 & Klaus Weber and Gerald F. Davis & Nov. 2000 \\
\hline $\begin{array}{l}\text { No. } 340 \text { The Costs and Benefits of Euro-isation in Central-Eastern } \\
\text { Europe Before or Instead of EMU Membership }\end{array}$ & D. Mario Nuti & Oct. 2000 \\
\hline No. 339 Debt Overhang and Barter in Russia & $\begin{array}{l}\text { Sergei Guriev, Igor Makarov and } \\
\text { Mathilde Maurel }\end{array}$ & 2000 \\
\hline $\begin{array}{l}\text { No. } 338 \text { Firm Performance and the Political Economy of Corporate } \\
\text { Governance: Survey Evidence for Bulgaria, Hungary, Slovakia and } \\
\text { Slovenia }\end{array}$ & $\begin{array}{l}\text { Patrick Paul Walsh and Ciara } \\
\text { Whela }\end{array}$ & July 2000 \\
\hline No. 337 Investment and Instability & $\begin{array}{l}\text { Nauro F. Campos and Jeffrey B. } \\
\text { Nugent }\end{array}$ & May 2000 \\
\hline $\begin{array}{l}\text { No. } 336 \text { The Evolution of the Insurance Sector in Central and } \\
\text { Eastern Europe and the former Soviet Union }\end{array}$ & Robert B.K. Pye & Aug. 2000 \\
\hline $\begin{array}{l}\text { No. } 335 \text { Institutional Technology and the Chains of Trust: Capital } \\
\text { Markets and Privatization in Russia and the Czech Republic }\end{array}$ & Bruce Kogut and Andrew Spicer & Aug. 2000 \\
\hline No. 334 The Evolution of Market Integration in Russia & $\begin{array}{l}\text { Daniel Berkowitz and David N. } \\
\text { DeJong }\end{array}$ & Aug. 2000 \\
\hline No. $333 \mathrm{E}$ & László Halpern and Gábor Körösi & July 2000 \\
\hline No. 332 Search-Money-and-Barter Models of Financial Stabilization & $\begin{array}{l}\text { S.I. Boyarchenko and S.Z. } \\
\text { Levendorskii }\end{array}$ & July 2000 \\
\hline
\end{tabular}




\begin{tabular}{|c|c|c|}
\hline $\begin{array}{l}\text { No. } 331 \text { Worker Training in a Restructuring Economy: Evidence from } \\
\text { the Russian Transition }\end{array}$ & $\begin{array}{l}\text { Mark C. Berger, John S. Earle } \\
\text { and Klara Z. Sabirianova }\end{array}$ & Aug. 2000 \\
\hline $\begin{array}{l}\text { No. } 330 \text { Economic Development in Palanpur 1957-1993: A Sort of } \\
\text { Growth }\end{array}$ & Peter Lanjouw & Aug. 2000 \\
\hline $\begin{array}{l}\text { No. } 329 \text { Trust, Organizational Controls, Knowledge Acquisition from } \\
\text { the Foreign Parents, and Performance in Vietnamese International Joint } \\
\text { Ventures }\end{array}$ & $\begin{array}{l}\text { Marjorie A. Lyles, Le Dang } \\
\text { Doanh, and Jeffrey Q. Barden }\end{array}$ & June 2000 \\
\hline $\begin{array}{l}\text { No. } 328 \text { Comparative Advertising in the Global Marketplace: The } \\
\text { Effects of Cultural Orientation on Communication }\end{array}$ & $\begin{array}{l}\text { Zeynep Gürhan-Canli and } \\
\text { Durairaj Maheswaran }\end{array}$ & Aug. 2000 \\
\hline No. 327 Post Privatization Enterprise Restructuring & Morris Bornstein & July 2000 \\
\hline No. 326 Who is Afraid of Political Instability? & $\begin{array}{l}\text { Nauro F. Campos and Jeffrey B. } \\
\text { Nugent }\end{array}$ & July 2000 \\
\hline No. 325 Business Groups, the Financial Market and Modernization & Raja Kali & June 2000 \\
\hline $\begin{array}{l}\text { No. } 324 \text { Restructuring with What Success? A Case Study of Russian } \\
\text { Firms }\end{array}$ & Susan Linz & July 2000 \\
\hline $\begin{array}{l}\text { No. } 323 \text { Priorities and Sequencing in Privatization: Theory and } \\
\text { Evidence from the Czech Republic }\end{array}$ & $\begin{array}{l}\text { Nandini Gupta, John C. Ham and } \\
\text { Jan Svejnar }\end{array}$ & May 2000 \\
\hline $\begin{array}{l}\text { No. } 322 \text { Liquidity, Volatility, and Equity Trading Costs Across } \\
\text { Countries and Over Time }\end{array}$ & $\begin{array}{l}\text { Ian Domowitz, Jack Glen and } \\
\text { Ananth Madhavan }\end{array}$ & Mar. 2000 \\
\hline $\begin{array}{l}\text { No. } 321 \text { Equilibrium Wage Arrears: A Theoretical and Empirical } \\
\text { Analysis of Institutional Lock-In }\end{array}$ & $\begin{array}{l}\text { John S. Earle and Klara Z. } \\
\text { Sabirianova }\end{array}$ & Oct. 2000 \\
\hline No. 320 Rethinking Marketing Programs for Emerging Markets & $\begin{array}{l}\text { Niraj Dawar and Amitava } \\
\text { Chattopadhyay }\end{array}$ & June 2000 \\
\hline $\begin{array}{l}\text { No. } 319 \text { Public Finance and Low Equilibria in Transition Economies: } \\
\text { the Role of Institutions }\end{array}$ & $\begin{array}{l}\text { Daniel Daianu and Radu } \\
\text { Vranceanu }\end{array}$ & 2000 \\
\hline $\begin{array}{l}\text { No. } 318 \text { Some Econometric Evidence on the Effectiveness of Active } \\
\text { Labour Market Programmes in East Germany }\end{array}$ & $\begin{array}{l}\text { Martin Eichler and Michael } \\
\text { Lechner }\end{array}$ & June 2000 \\
\hline No. 317 A Model of Russia's "Virtual Econ & R.E Ericson and B.W Ickes & Iay 2000 \\
\hline $\begin{array}{l}\text { No. } 316 \text { Financial Institutions, Financial Contagion, and Financial } \\
\text { Crises }\end{array}$ & $\begin{array}{l}\text { Haizhou Huang and Chenggang } \\
\mathrm{Xu}\end{array}$ & Mar. 2000 \\
\hline $\begin{array}{l}\text { No. } 315 \text { Privatization versus Regulation in Developing Economies: The } \\
\text { Case of West African Banks }\end{array}$ & $\begin{array}{l}\text { Jean Paul Azam, Bruno Biais, and } \\
\text { Magueye Dia }\end{array}$ & Feb. 2000 \\
\hline $\begin{array}{l}\text { No. } 314 \text { Is Life More Risky in the Open? Household Risk-Coping and } \\
\text { the Opening of China's Labor Markets }\end{array}$ & John Giles & Apr. 2000 \\
\hline $\begin{array}{l}\text { No. } 313 \text { Networks, Migration and Investment: Insiders and Outsiders in } \\
\text { Tirupur's Production Cluster }\end{array}$ & $\begin{array}{l}\text { Abhijit Banerjee and Kaivan } \\
\text { Munshi }\end{array}$ & Mar. 2000 \\
\hline $\begin{array}{l}\text { No. } 312 \text { Computational Analysis of the Impact on India of the Uruguay } \\
\text { Round and the Forthcoming WTO Trade Negotiations }\end{array}$ & $\begin{array}{l}\text { Rajesh Chadha, Drusilla K. } \\
\text { Brown, Alan V. Deardorff and } \\
\text { Robert M. Stern }\end{array}$ & Mar. 2000 \\
\hline No. 311 Subsidized Jobs for Une & Jan. C. van Ours & May 2000 \\
\hline No. 310 Determinants of Managerial Pay in the Czech Republic & $\begin{array}{l}\text { Tor Eriksson, Jaromir Gottvald } \\
\text { and Pavel Mrazek }\end{array}$ & May 2000 \\
\hline $\begin{array}{l}\text { No. } 309 \text { The Great Human Capital Reallocation: An Empirical Analysis } \\
\text { of Occupational Mobility in Transitional Russia }\end{array}$ & Klara Z. Sabirianova & Oct. 2000 \\
\hline No. 308 Economic Development, Legality, and the Transplant Effect & $\begin{array}{l}\text { Daniel Berkowitz, Katharina } \\
\text { Pistor, and Jean-Francois Richard }\end{array}$ & Feb. 2000 \\
\hline $\begin{array}{l}\text { No. } 307 \text { Community Participation, Teacher Effort, and Educational } \\
\text { Outcome: The Case of El Salvador's EDUCO Program }\end{array}$ & Yasuyuki Sawada & Nov. 1999 \\
\hline No. 306 Gender Wage Gap and Segregation in Late Transition & Stepan Jurajda & May 2000 \\
\hline $\begin{array}{l}\text { No. } 305 \text { The Gender Pay Gap in the Transition from Communism: } \\
\text { Some Empirical Evidence }\end{array}$ & Andrew Newell and Barry Reilly & May 2000 \\
\hline No. 304 Post-Unification Wage Growth in East Germany & Jennifer Hunt & Nov. 1998 \\
\hline $\begin{array}{l}\text { No. } 303 \text { How Does Privatization Affect Workers? The Case of the } \\
\text { Russian Mass Privatization Program }\end{array}$ & Elizabeth Brainerd & May 2000 \\
\hline $\begin{array}{l}\text { No. } 302 \text { Liability for Past Environmental Contamination and } \\
\text { Privatization }\end{array}$ & Dietrich Earnhart & Mar. 2000 \\
\hline
\end{tabular}


The entire Working Paper Series is available at: www.wdi.bus.umich.edu

\begin{tabular}{|c|c|c|}
\hline No. 301 Varieties, Jobs and EU Enlargement & $\begin{array}{l}\text { Tito Boeri and Joaquim Oliveira } \\
\text { Martins }\end{array}$ & May 2000 \\
\hline No. 300 Employer Size Effects in Russia & Todd Idson & Apr. 2000 \\
\hline $\begin{array}{l}\text { No. } 299 \text { Information Complements, Substitutes, and Strategic Product } \\
\text { Design }\end{array}$ & $\begin{array}{l}\text { Geoffrey G. Parker and Marshall } \\
\text { W. Van Alstyne }\end{array}$ & Mar. 2000 \\
\hline $\begin{array}{l}\text { No. } 298 \text { Markets, Human Capital, and Inequality: Evidence from Rural } \\
\text { China }\end{array}$ & $\begin{array}{l}\text { Dwayne Benjamin, Loren Brandt, } \\
\text { Paul Glewwe, and Li Guo }\end{array}$ & May 2000 \\
\hline No. 297 Corporate Governance in the Asian Financial Crisis & $\begin{array}{l}\text { Simon Johnson, Peter Boone, } \\
\text { Alasdair Breach, and Eric } \\
\text { Friedman }\end{array}$ & Nov. 1999 \\
\hline No. 296 Competition and Firm Performance: Lessons from Russia & J. David Brown and John S. Earle & Mar. 2000 \\
\hline No. 295 Wage Determination in Russia: An Econometric Investigation & $\begin{array}{l}\text { Peter J. Luke and Mark E. } \\
\text { Schaffer }\end{array}$ & Mar. 2000 \\
\hline $\begin{array}{l}\text { No. 294: Can Banks Promote Enterprise Restructuring?: Evidence From } \\
\text { a Polish Bank's Experience }\end{array}$ & John P. Bonin and Bozena Leven & Mar. 2000 \\
\hline No. 293: Why do Governments Sell Privatised Companies Abroad? & $\begin{array}{l}\text { Bernardo Bortolotti, Marcella } \\
\text { Fantini and Carlo Scarpa }\end{array}$ & Mar. 2000 \\
\hline $\begin{array}{l}\text { No. 292: Going Public in Poland: Case-by-Case Priv } \\
\text { Privatization and Private Sector Initial Public Offerin }\end{array}$ & Wolfgang Aussenegg & Dec. 1999 \\
\hline $\begin{array}{l}\text { No. 291: Institutional Technology and the Chains of Trust: Capital } \\
\text { Markets and Privatization in Russia and the Czech Republic }\end{array}$ & Bruce Kogut and Andrew Spicer & Mar. 1999 \\
\hline No. 290: Banking Crises and Bank Rescues: The Effect of Reputation & Jenny Corbett and $\mathrm{J}$ & Jan. 2000 \\
\hline $\begin{array}{l}\text { No. 289: Do Active Labor Market Policies Help Unemployed Workers } \\
\text { to Find and Keep Regular Jobs? }\end{array}$ & Jan C. van Ours & Feb. 2000 \\
\hline of the New Elite in Zimbabwe & elk & Feb. 2000 \\
\hline $\begin{array}{l}\text { ransition Economies: Competing Explanations } \\
\text { Cata }\end{array}$ & fijann & Jan. 2000 \\
\hline $\begin{array}{l}\text { No. 286: The Quest for Pension Reform: Poland's Security through } \\
\text { Diversity }\end{array}$ & $\begin{array}{l}\text { Marek Góra and Mi } \\
\text { Rutkowski }\end{array}$ & 2000 \\
\hline No. 285: Disorganization and Financial Collapse & $\mathrm{a}$ & 99 \\
\hline No. 284: Co & $\begin{array}{l}\text { Yingyi Qian, Gérard Roland and } \\
\text { Chenggang Xu }\end{array}$ & May 1999 \\
\hline $\begin{array}{l}\text { No. 283: Why Russian Workers Do Not Move: Attachment of Wo } \\
\text { Through In-Kind Payments }\end{array}$ & Guido Friebel and Sergei Guriev & Oct. 1999 \\
\hline No. 282: Lessons From Fiascos in Russian Corporate Governance & tt B. Fox and Michael A. & Oct. 1999 \\
\hline $\begin{array}{l}\text { No. 281: Income Distribution and Price Controls: Targeting a Social } \\
\text { Safety Net During Economic Transition }\end{array}$ & $\begin{array}{l}\text { Michael Alexeev and James } \\
\text { Leitzel }\end{array}$ & Mar. 1999 \\
\hline $\begin{array}{l}\text { No. 280: Starting Positions, Reform Speed, and Economic Outcomes in } \\
\text { Transitioning Economies }\end{array}$ & William Hallagan and Zhang Jun & Jan. 2000 \\
\hline No. 279: The Value of Prominent Directors & $\begin{array}{l}\text { Yoshiro Miwa \& J. Mark } \\
\text { Ramseyer }\end{array}$ & Oct. 1999 \\
\hline No. 278: T & & pr. 1998 \\
\hline $\begin{array}{l}\text { No. 277: The Developmental Consequences of Foreign Direct } \\
\text { Investment in the Transition from Socialism to Capitalism: The } \\
\text { Performance of Foreign Owned Firms in Hungary }\end{array}$ & Lawrence Peter King & Sept. 1999 \\
\hline $\begin{array}{l}\text { No. 276: Stability and Disorder: An Evolutionary Analysis of Russia's } \\
\text { Virtual Economy }\end{array}$ & $\begin{array}{l}\text { Clifford Gaddy and Barry W. } \\
\text { Ickes }\end{array}$ & Nov. 1999 \\
\hline $\begin{array}{l}\text { No. 275: Limiting Government Predation Through Anonymous } \\
\text { Banking: A Theory with Evidence from China. }\end{array}$ & $\begin{array}{l}\text { Chong-En Bai, David D. Li, } \\
\text { Yingyi Qian and Yijiang Wang }\end{array}$ & July 1999 \\
\hline No. 274: Transition with Labour Supply & Tito Boeri & Dec. 1999 \\
\hline $\begin{array}{l}\text { No. 273: Sectoral Restructuring and Labor Mobility: A Co } \\
\text { Look at the Czech Republic }\end{array}$ & Vit Sorm and Katherine Terrell & Nov. 1999 \\
\hline
\end{tabular}




\begin{tabular}{|c|c|c|}
\hline $\begin{array}{l}\text { No. 272: Published in: Journal of Comparative Economics "Returns to } \\
\text { Human Capital Under the Communist Wage Grid and During the } \\
\text { Transition to a Market Economy" Vol. 27, pp. 33-60 } 1999 .\end{array}$ & $\begin{array}{l}\text { Daniel Munich, Jan Svejnar and } \\
\text { Katherine Terrell }\end{array}$ & Oct. 1999 \\
\hline $\begin{array}{l}\text { No. 271: Barter in Russia: Liquidity Shortage Versus Lack of } \\
\text { Restructuring }\end{array}$ & $\begin{array}{l}\text { Sophie Brana and Mathilde } \\
\text { Maurel }\end{array}$ & June 1999 \\
\hline $\begin{array}{l}\text { No. 270: Tests for Efficient Financial Intermediation with Application to } \\
\text { China }\end{array}$ & Albert Park and Kaja Sehrt & Mar. 1999 \\
\hline $\begin{array}{l}\text { No. 269a: Russian Privatization and Corporate Governance: What Went } \\
\text { Wrong? }\end{array}$ & $\begin{array}{l}\text { Bernard Black, Reinier Kraakman } \\
\text { and Anna Tarassova }\end{array}$ & May 2000 \\
\hline $\begin{array}{l}\text { No. 269: Russian Privatization and Corporate Governance: What Went } \\
\text { Wrong? }\end{array}$ & $\begin{array}{l}\text { Bernard Black, Reinier Kraakman } \\
\text { and Anna Tarassova }\end{array}$ & Sept. 1999 \\
\hline No. 268: Are Russians Really Ready for Capitalism? & Susan Linz & Sept. 1999 \\
\hline No. 267: Do Stock Markets Promote Economic Growth? & $\begin{array}{l}\text { Randall K. Filer, Jan Hanousek } \\
\text { and Nauro Campos }\end{array}$ & Sept. 1999 \\
\hline $\begin{array}{l}\text { No. 266: Objectivity, Proximity and Adaptability in Corporate } \\
\text { Governance }\end{array}$ & $\begin{array}{l}\text { Arnoud W.A Boot and Jonathan } \\
\text { R. Macey }\end{array}$ & Sept. 1999 \\
\hline $\begin{array}{l}\text { No. 265: When the Future is not What it Used to Be: Lessons from the } \\
\text { Western European Experience to Forecasting Education and Training in } \\
\text { Transitional Economies }\end{array}$ & $\begin{array}{l}\text { Nauro F. Campos, Gerard } \\
\text { Hughes, Stepan Jurajda, and } \\
\text { Daniel Munich }\end{array}$ & Sept. 1999 \\
\hline $\begin{array}{l}\text { No. 264: The Institutional Foundation of Foreign-Invested Enterprises } \\
\text { (FIEs) in China }\end{array}$ & Yasheng Huang & Sept. 1999 \\
\hline $\begin{array}{l}\text { No. 263: The Changing Corp } \\
\text { for Transition and Developing }\end{array}$ & and Ernst-Ludwig & June 1999 \\
\hline No. 262: Law Enforcement and Transition & \begin{tabular}{|l} 
Gerard Rolan \\
Verdier
\end{tabular} & May 1999 \\
\hline $\begin{array}{l}\text { No. 261: Soft Budget Constraints, Pecuniary Externality, and the Dual } \\
\text { Track System }\end{array}$ & Jiahua Che & June 2000 \\
\hline $\begin{array}{l}\text { No. 260: Missing Market in Labor Quality: The Role of Quality Markets } \\
\text { in Transition }\end{array}$ & on & July 1999 \\
\hline $\begin{array}{l}\text { No. 259: Do Corporate Global Environmental Standards in Emerging } \\
\text { Markets Create or Destroy Market Value }\end{array}$ & d Yeung & 1999 \\
\hline No. 258: Public Training and Outflows from Unemployment & & June 1999 \\
\hline $\begin{array}{l}\text { No. 257: Ownership Versus Environment: Why are Public Sector Firms } \\
\text { Inefficient? }\end{array}$ & $\begin{array}{l}\text { Bartel and Ann E. } \\
\text { on }\end{array}$ & June 1999 \\
\hline $\begin{array}{l}\text { No. 256: Taxation and Evasion in the Presence of Exortion by } \\
\text { Organized Crime }\end{array}$ & $\begin{array}{l}\text { Alexeev, Eckhard } \\
\text { fan Osborne }\end{array}$ & Nov. 1999 \\
\hline No. 255: Revisiting Hungary’s Bankruptcy Episode & $\begin{array}{l}\text { John P. Bonin and Mark E. } \\
\text { Schaffer }\end{array}$ & Sept. 1999 \\
\hline No. 254: FDI in & Marina v.N Whitman & June 1999 \\
\hline $\begin{array}{l}\text { No. 253: The Asian Financial Crisis: What Happened, and What is to be } \\
\text { Done }\end{array}$ & $\begin{array}{l}\text { Jeffrey D. Sachs and Wing Thye } \\
\text { Woo }\end{array}$ & Jan. 1999 \\
\hline No. 252: Organizational Law as Asset Partitioning & $\begin{array}{l}\text { Henry Hansmann and Reinier } \\
\text { Kraakman }\end{array}$ & Sept. 1999 \\
\hline $\begin{array}{l}\text { No. 251: Consumer Behavior Research in Emerging Consumer Markets: } \\
\text { the Case of the Optimum Stimulation Level in South Africa }\end{array}$ & $\begin{array}{l}\text { Jan-Benedict E. M. Steenkamp } \\
\text { and Steven M. Burgess }\end{array}$ & Sept. 1999 \\
\hline $\begin{array}{l}\text { No. 250: Property Rights Formation and the Organization of Exchange } \\
\text { and Production in Rural China }\end{array}$ & $\begin{array}{l}\text { Matthew A. Turner, Loren } \\
\text { Brandt, and Scott Rozelle }\end{array}$ & July 1998 \\
\hline $\begin{array}{l}\text { No. 249: Impacts of the Indonesian Economic Crisis: Price Changes and } \\
\text { the Poor }\end{array}$ & $\begin{array}{l}\text { James Levinsohn, Steven Berry, } \\
\text { and Jed Friedman }\end{array}$ & June 1999 \\
\hline $\begin{array}{l}\text { No. 248: Internal Barriers in the Transition of Enterprises from Central } \\
\text { Plan to Market }\end{array}$ & Charalambos Vlachoutsicos & July 1999 \\
\hline $\begin{array}{l}\text { No. 247: Spillovers from Multinationals in Developing Countries: the } \\
\text { Mechanisms at Work }\end{array}$ & Richard E. Caves & June 1999 \\
\hline $\begin{array}{l}\text { No. 246: Dynamism and Inertia on the Russian Labour Market: A } \\
\text { Model of Segmentation }\end{array}$ & $\begin{array}{l}\text { Irena Grosfeld, Claudia Senik- } \\
\text { Leygonie, Thierry Verdier, Stanislav } \\
\text { Kolenikov and Elena Paltseva }\end{array}$ & May 1999 \\
\hline
\end{tabular}

